Gadjah Mada International Journal of Business

January 2003, Vol. 5, No. 1, pp. 1-14

\title{
NORMATIVE MODERATORS OF IMPULSE BUYING BEHAVIOR
}

\author{
Danes Jaya Negara \\ Basu Swastha Dharmmesta
}

Prior research has presented the moderating role of normative evaluations in the relationship between the impulsive buying trait and consumers' buying behaviors. In this article the authors show that consumer tendency to buy something spontaneous, unreflectively and immediately can be perceived as a factor which describes buying impulsiveness. This article also shows conceptual and empirical evidence that there is some support for the moderating role of normative evaluations in the relationship between buying impulsiveness and impulse buying behaviors. Significance occurs when consumers believe that act on impulse is suitable. The result suggests that consumers' normative evaluation can moderate the link between the trait and behavioral aspects of impulse buying.

Keywords: buying impulsiveness; impulse buying; normative evaluations 


\section{Introduction}

For most people, buying is a normal and routine part of daily life. In consumer behavior theory, consumers have a purchasing pattern. One of the purchase behaviors is impulse buying or unplanned purchasing. "Impulse" or "unplanned" purchasing ${ }^{1}$ is a familiar term to most business executives and marketing academicians today. Indeed, it is common to refer to certain product as "impulse items" and/or to "account for" certain kinds of behavior by classifying it as impulse purchasing (Kollat and Willet 1969). According to the history, impulse behavior has a long history of being associated with immaturity, primitivism, foolishness, "defect of the will," lower intelligence, and even social deviance and criminality. More recently, impulsive behavior has been characterized as specious thinking (Ainslic 1975); which leads to myopic and inconsistent behavior (Stigler and Becker 1977); consumer with positive normative evaluation are more likely to act in a way that is consistent with the degree to which they posses the buying impulsiveness trait (Rook and Fisher 1995).

In the consumption realm, impulsive behavior has been linked with "being bad," and with negative consequences in the areas of personal finance, post purchase satisfaction, social reactions, and overall self esteem (Rook 1987; Rook and Hoch 1985). Yet, it is possible to conceive of consumption situation in which impulse buying would be viewed as normatively neutral; or even positively sanctioned behavior (Rook and Fisher 1995). They gave good examples, they are, a spontaneous gift for an ill friend, a sudden decision to pick up the tab for a meal, or simply taking advantage of a two-for-one in-store special are impulse buying instances that may present, respectively, kind, generous, and practical activities. When impulse buying is more virtuously motivated, it is likely to elicit more positive normative evaluations.

The probability that consumers actually engage in impulse buying presumably depend both on the degree to which they posses impulsive buying trait tendencies and on their normative judgments that may prescribe or permit a particular impulsive purchase. In theory, when a generally impulsive consumer experiences an impulse buying stimulus, and subsequently evaluates the prospective purchase as appropriate, both trait and normative influence are harmonious, thereby making and impulsive purchase likely. On the other hand, if negative normative evaluations arise in a purchase situation, the consumer's trait tendencies may be thwarted, and even a highly impulsive buyer will be less likely to act on his or her buying impulses (Rook and Fisher 1995).

This study follows the methodological analyses of Rook and Fisher's study by measuring relationship between the trait and normative aspects of impulse buying. The authors first review the theoretical bases for conceptualizing and operationalizing these variables; then present a study that evaluates the moderating role of normative evaluations in the relationship between the buying impulsiveness trait and subsequent buying behavior.

The main objective of the research is to analyze the relationship between the buying impulsiveness trait and subsequent behavior of the consumers. The other objective is also to analyze the relationship

\footnotetext{
${ }^{1}$ As used in this paper, "impulse" and "unplanned" are synonymous. Iyer (1989) states, “.....all impulse buying is unplanned, but all unplanned purchase are not necessarily bought on impulse. Unplanned purchasing includes items for which the purchasing decision was made in the store and not prior to entering the store."
} 
Negara \& Dharmmesta - Normative Moderators of Impulse Buying Behavior

between impulsive tendencies and impulse buying behavior of the consumers.

\section{The Nature of Impulse Buying}

The general trait of impulsiveness, or impulsivity (the term are used interchangeably), has been studied extensively by clinical and developmental psychologists, education researchers, and criminologists (Eysenck et al. 1980). Impulse buying, or as some marketers prefer to call it unplanned purchasing - is another consumer purchasing pattern. As the term implies, the purchase was not specifically planned (Loudon and Bitta 1993). Assael (1995) call it - purchase that consumers do not plan before going to the store. In contrast, complex decision making assumes a preplanning process. According to Assael, there are two basic reasons for an unplanned purchase. First, the time and effort involved in searching for alternatives outside the store may not be worth the trouble, and consumers buy largely on a reminder basis (that is, by inertia). Second, consumers may seek variety or novelty and thus buy on impulse (that is, by limited decision-making). Hawkins et al. (1998) defined impulse purchase as purchase made in a store that are different from those the consumer planned to make prior to entering the store. According to Hawkins et al., that unplanned purchase implies a lack of rationality or alternative evaluation is not necessarily true (see Iyer 1989; Park et al. 1989, for detail discussion). Considering in-store purchase decision as the results of additional information processing within the store leads to much more useful marketing strategies than considering these purchases to be random or illogical (Cobb and Hoyer 1986; Bawa et al. 1989; Russo and Lecleric 1994).
Presently, over a dozen psychological measures of general impulsiveness exist, yet there is no current theory-driven and validated measure of buying impulsiveness. On the other hand, evidence shows that a considerable number of consumers think of themselves as "impulse buyers." Between 1975 and 1992, an average of 38 percent of the adults in an annual national survey responded affirmatively to the statement: "I am an impulse buyer" (DDB Needham Annual Lifestyle Survey 1974 - 1993). There are also several studies that have indicated the significant and growing trend toward unplanned purchasing. Here are some of the conclusions on the extent of impulse buying: (1) more than 33 percent of all purchases in variety and drugstore are unplanned (Clover 1950), (2) one half of buying decision in supermarket are unplanned (Prasad 1975), and (3) thirty-nine percent of all department store shoppers and 62 percent of all discount store shoppers purchases at least one item on an unplanned basis (Robertson and Hirschman 1978).

In the most recent the extent of purchasing that is not specifically planned, in the United States and Canada, showed that consumers make most item or brand decision after entering the store (POPAI 1995). First aid products (93 percent in-store decision) and oral hygiene products such as toothpaste and mouthwash (89 percent instore decision) represent major opportunities. This finding, accompanied by psychologists' enduring treatment of impulsiveness as a basic human trait, encourages our belief that individual's impulse buying tendencies can be conceptualized as a consumer's trait that we label as buying impulsiveness.

Rook and Fisher (1995) hypothesize that buying impulsive is a unidimensional 
Gadjah Mada International Journal of Business, January 2003, Vol. 5, No. 1

Table 1. A Summary of Findings Concerning the Reason for Unplanned Purchasing

\begin{tabular}{|c|c|c|c|c|c|}
\hline Investigator (s) & Year & $\begin{array}{l}\text { Reason for Purchasing } \\
\text { Unplanned } \\
\text { Purchasing }\end{array}$ & $\begin{array}{l}\text { Type of } \\
\text { Outlets }\end{array}$ & $\begin{array}{l}\text { Type of } \\
\text { Products }\end{array}$ & $\begin{array}{l}\text { Rate of } \\
\text { Unplaned } \\
\text { Purchasing }\end{array}$ \\
\hline $\begin{array}{l}\text { Cook } \\
\text { Harris } \\
\text { Kotzman, and } \\
\text { Evanson }\end{array}$ & $\begin{array}{l}1964 \\
1958\end{array}$ & $\begin{array}{l}\text { Shelf design parameter: } \\
\text { Shelf-spacing, Shelf-height } \\
\text { Shelf-spacing }\end{array}$ & Grocery & Food & N.A \\
\hline $\begin{array}{l}\text { Kollat and } \\
\text { Willet }\end{array}$ & $\begin{array}{l}1967 / \\
1969\end{array}$ & $\begin{array}{l}\text { Product and consumer's } \\
\text { characteristics }\end{array}$ & Grocery & Non staples & $50.5 \%$ \\
\hline Granbois & 1968 & Proclivity to visit store & Grocery & Food & N.A \\
\hline $\begin{array}{l}\text { McKenna } \\
\text { McClure and } \\
\text { West } \\
\text { Progressive } \\
\text { Grocer }\end{array}$ & $\begin{array}{l}1966 / \\
1969\end{array}$ & Point-of-purchase & $\begin{array}{l}\text { Grocery } \\
\text { Department } \\
\text { Discount }\end{array}$ & 25 product & $\begin{array}{l}52.5 \% \\
43.6 \% \\
35.8 \%\end{array}$ \\
\hline Prasad & 1975 & N.A & $\begin{array}{l}\text { Department } \\
\text { Discount }\end{array}$ & Non food & $\begin{array}{l}39.3 \% \\
62.4 \%\end{array}$ \\
\hline Bellenger et al. & 1978 & N.A & Department & $\begin{array}{l}20 \text { product } \\
\text { categories }\end{array}$ & $37.7 \%$ \\
\hline $\begin{array}{l}\text { Rook and Hoch } \\
\text { Rook }\end{array}$ & $\begin{array}{l}1985 \\
1987\end{array}$ & $\begin{array}{l}\text { Sudden and spontaneous } \\
\text { Psychological disequilibrium } \\
\text { Psychological conflict } \\
\text { Lowering utility-maximizing } \\
\text { Disregard for consequences }\end{array}$ & $\begin{array}{l}\text { At home } \\
\text { variety }\end{array}$ & Product & N.A \\
\hline Iyer & 1989 & $\begin{array}{l}\text { Time Pressure } \\
\text { Knowledge of shopping } \\
\text { environment }\end{array}$ & Grocery & 32 product & N.A \\
\hline Donovan et al. & 1994 & $\begin{array}{l}\text { Pleasure and arousal in } \\
\text { store }\end{array}$ & $\begin{array}{l}\text { Discount } \\
\text { department }\end{array}$ & N.A & N.A \\
\hline $\begin{array}{l}\text { POPAI / } \\
\text { DUPONT }\end{array}$ & 1995 & N.A & $\begin{array}{l}\text { Grocery } \\
\text { product } \\
\text { Drug store }\end{array}$ & $\begin{array}{l}\text { Over } 50 \\
\text { product } \\
\text { categories }\end{array}$ & $\begin{array}{l}93.0 \% \\
89.0 \%\end{array}$ \\
\hline $\begin{array}{l}\text { Rook and } \\
\text { Fisher }\end{array}$ & 1995 & Normative evaluation & Mall & Compact disc & sc N.A \\
\hline
\end{tabular}

N.A $=$ not available

4 
Negara \& Dharmmesta - Normative Moderators of Impulse Buying Behavior

construct that embodies consumers' tendencies both to think and to act in identifiable and distinctive ways. Specifically, they define buying impulsiveness as a consumer's tendency to buy spontaneously, unreflectively, immediately, and kinetically. Highly impulsive buyers are more likely to experiences spontaneous buying stimuli; their shopping lists are more "open" and receptive to sudden, unexpected buying ideas. Also, their thinking is likely to be relatively unreflective, prompted by physical proximity to a desired product, dominated by emotional attraction to it, and absorbed by the promise of immediate gravitation (Hoch and Loewenstein 1991). As a result, impulsive buyer are more likely to act on whim and to respond affirmatively and immediately to their buying impulses. In extreme cases, impulsive behavior is almost entirely stimulus driven; a buying impulse translates directly into an immediate, yielding, and physical response, or, as Rook (1987) describes it, a consumer "spasm." Moreover, impulsive buyers are likely to experience buying impulses more frequently and strongly than other consumers.

To have an impulse, however, is not necessarily to act on it, as various factors may intervene between the impetus and the action. Even, highly impulsive buyers do not necessarily give in to every spontaneous buying demand, as a variety of factors may alert consumers to the need for immediate deliberation and consequently "interrupt" the transition from impulsive feeling to impulsive action (Bettman 1979). Factors such as a consumer's economic position, time pressure, social visibility, and perhaps even the buying impulse itself can trigger the need to evaluate a prospective impulsive purchase quickly (Hoch and Loewenstein 1991). Hook and Fisher proposes that one likely intervening fac- tors arises from consumers' subjective, normative evaluation of acting on their buying impulse. Specifically, they hypothesize that normative influences operate as a moderator of consumers' impulse buying trait tendencies.

Table 1 summarizes the findings in this area as reported by Cobb and Hoyer (1986) from 1958 to 1986 . As the table indicates, unplanned purchasing is not limited to any one type of product or retail setting. It does seem more likely to occur on an overall basis in supermarkets and discount stores than in specialty and department stores.

\section{The Rook and Fisher Framework}

After selectively reviewing the relevant literature in clinical and developmental psychology, economics, criminology, and consumer behavior, Rook and Fisher (1995) sought to identify the normative dimensions that most likely to influence consumer's impulse about in a particular buying situation. Briefly, they found several characteristics from these literatures, namely: (1) there are two basic humans thought processes, one tend toward the rational and socialized, while the other impulsive behavior that is likely to be evaluated as immature; (2) self-centered, short signed and wasteful, and (3) linked to post purchased financial problems, product disappointment, guilt feeling, and disapproval.

Rook and Fisher (1995) further noted that there is an enduring and pervasive tendency to interpret impulsive behavior as irrational, immature, wasteful, and risky. To some extent, negative views about impulsive behavior derive from interest in exceptional cases that involve significant departures from existing social behavior 
norms. However, the motives for and consequences of impulse buying for many individuals are less problematic. Much impulse buying arguably involves only minor infractions of relevant norms. In other hypothetical situations, normative influence might even encourage acting on impulse as the right thing to do.

Rook and Hoch (1985) presented a detailed discussion of impulse from variety literature. They identified five crucial elements that distinguish impulsive from non impulsive consumer behavior. First impulsive behavior involves a sudden and spontaneous desire to act, representing a clear departure from the previous ongoing behavior stream. This notion of a rapid change in psychological states fits in well with neurophysiological representations, where an impulse is described as "a wave of active change continuing along a nerve fiber" (Wolman 1977). In the same way that these neurological impulses triggers some biological response, psychological impulse can be viewed as stimulation agents driven by conscious and unconscious mental processes.

The sudden urge to buy on impulse can throw the consumer into a state of psychological disequilibrium. This second feature of impulse buying can cause an individual to feel temporarily out-ofcontrol. There is an extensive literature on the developmental and clinical aspect of impulsivity and impulse control. The third element of consumer impulsivity is the psychological conflict and struggle that may ensue (Thaler and Shefrin 1981). Often the consumer feels ambivalent toward the products that are impulse objects. Because people tend to overvalue proxy at satisfaction relative to more distant ones; the closer one is to being able to enjoy that immediate impulse, the harder it is to resist. To illustrate, consider the following two impulses. You are rummaging around the kitchen deciding what groceries you need to buy and you get a craving for Famous Amos Cookies. You are walking through a mall and the aroma of freshly baked Famous Amos Chocolate Chip Cookies instantly overcomes you. Suppose that you were trying to stick to a diet: which impulse would be the hardest to resist? Most likely it would be the latter impulse, because the urge can be satisfied so quickly. People often feel that impulse need to be indulged either right now or never.

A fourth distinguishing aspect of impulse buying is that consumer's mills typically reduce their cognitive evaluation of product attributes. Weinberg and Gottwald (1982) believe that impulse buying involves distinctive transactional, affective states. Behavior is largely "automatic," high in affective activation, and low in intellectual control of the buying decision. Impulsive consumption is the antithesis of classical models of "economic man" as a rational expected utility maximize, yet impulse buying is not mindless, low involvement behavior. In fact, we see impulse buying as a most right after the impulse arises. The sudden urgency of the impulse requires the consumer's complete attention. Moreover, as conflict arises, cognitive activity may increase dramatically, depending upon whether the consumer has the motivation or ammunition to fight off the impulse.

Finally, people often consume impulsively without regard to the consequences. The framework must acknowledge the pathological aspects of impulsive consumption. Psychodynamic interpretations depict impulsivity as a form of neurotic behavior. Individual with impulsive pathologies seems to be living in a state of constant but stable chaos (with) little perspective about the future consequences of their current behavior. 
Negara \& Dharmmesta -Normative Moderators of Impulse Buying Behavior

\section{The Moderating Role of Normative Evaluations}

Normative perspective on individual behavior provides both general and specific guidelines for acceptable conduct in particular situations (Birenbaum and Sagarin 1976). This emphasis on the situational dimension is critical because even if consumers have generalized normative views about impulse buying, the most consequential influences are likely those that emerge when a consumer experiences a buying impulse in a particular situation. Moreover, different impulse buying situations tend to evoke varying normative evaluations. For example, impulse buying may be viewed as a socially acceptable way to spend five hundred thousand rupiah in lottery winning, but as bad to way to dispose of one's rent money. Even the most impulsive buyer probably will resist making an impulsive purchase that would cause him or her to be labeled as foolish, crazy, wasteful, or immature.

Once normative forces become salient, how do they interact with consumer's impulse buying tendencies and behavior? Much research on normative factors in consumer decision making relies on the perspective taken by Fishbein's theory of reasoned action (Ajzen and Fisbein 1977), in which subjective norms arise from individuals' predictions about how salient social referents will react to a considered behavior, coupled with individuals' motivation to comply with these normative expectations. However, the effect of subjective norms on behavior is viewed as mediated by individual's behavior intentions, which is compatible with the spontaneity and immediacy of impulse buying transactions that transpire, by definition, without prior intention.
As an alternative to the subjective norm component of the Fishbein model, Rook and Fisher (1995) propose that the relationship between the buying impulsiveness trait and the act of buying something on impulse is moderated by consumer's normative evaluations of making an impulsive purchase. At first glance, it might seem that normative evaluations are incompatible with impulsive purchase, and the rapidity with which such transactions typically occur does not preclude the likelihood that consumers are still thinking, feeling, and evaluating various retail stimuli, if only for a few seconds. Even consumers who rank high in buying impulsiveness may experience normative encouragement or discouragement when the urge to buy something on impulse strikes.

\section{Hypotheses}

Following Rook and Hoch (1985) and Rook and Fisher (1995), it was hypothesized that:

$H_{1}$ : When a consumer feels that impulse buying is acceptable in a particular context, a positive relationship should exist between the buying impulsiveness trait and subsequent behavior. Because normative constraint is absent, the consumer is free to act on his or her impulsive buying tendencies.

$H_{2}$ : The relationship between consumer's impulse buying tendencies and their impulse buying behavior should be strong when normative evaluations are approving but weaker when some negative normative threshold is reached, which mutes consumers' trait tendencies. 


\section{Method}

\section{Research Setting}

Following Rook and Fisher (1995), this study investigated the relationship between buying impulsiveness and consumers' buying behaviors. Although we assume that consumers who rank high on this trait buy things on impulse more frequently than do others, we hypothesize a moderating effect in which consumers' impulsive buying tendencies are filtered by their normative evaluations about acting on impulse in particular situations.

\section{Sample}

A sample of 160 graduate students at Master of Management Program and Mas- ter of Science in Management Program, Gadjah Mada University were recruited to participate in an impulse buying study. Respondents were asked to select one of a set purchase alternative in a hypotheticalbuying scenario. We conducted this task before administering the items designed to measure buying impulsiveness in order to disguise our research agenda from respondents and to avoid response biases that might have arisen if we had reversed the procedures.

\section{Measures of Buying Impulsiveness}

Twenty-five items measuring buying impulsiveness were generated from a review of prior research impulse buying phenomenology (Rook 1987) and from extant literature on general measures of

\section{Table 2. Confirmatory Factor Analysis Result}

\begin{tabular}{|c|c|c|c|c|}
\hline & Item & Factor & $\begin{array}{c}\text { Mean } \\
\text { Loading }\end{array}$ & $\begin{array}{l}\text { Standard } \\
\text { Deviation }\end{array}$ \\
\hline 1. & I suddenly feel compelled to buy something & .83 & 3.24 & 1.29 \\
\hline 2. & $\begin{array}{l}\text { If just happen very fast, described the way I buy } \\
\text { things }\end{array}$ & .77 & 3.02 & 1.21 \\
\hline 3. & I don't need to think about it much & .74 & 2.78 & 1.19 \\
\hline 4. & "Buy now, think about it later" describes me & .72 & 2.62 & 1.08 \\
\hline 5. & When I see things, I buy things & .70 & 2.57 & 1.23 \\
\hline 6. & $\begin{array}{l}\text { Sometimes I feel like buying things on the } \\
\text { spontaneous }\end{array}$ & .68 & 2.43 & 1.14 \\
\hline 7. & $\begin{array}{l}\text { I buy things accordance how I feel at the } \\
\text { moment }\end{array}$ & .64 & 3.25 & 1.23 \\
\hline 8. & I have a care plan most of my purchase & .63 & 2.94 & 1.16 \\
\hline & $\begin{array}{l}\text { Sometimes I am a bit heedless about what I } \\
\text { purchase }\end{array}$ & .62 & 2.89 & 1.13 \\
\hline & $\begin{array}{l}\text { I have a real hard time in store without things } \\
\text { grabbing my attention }\end{array}$ & .61 & 3.01 & 1.09 \\
\hline
\end{tabular}

Response format: $1=$ strongly disagree; $5=$ strongly agree. 
Negara \& Dharmmesta -Normative Moderators of Impulse Buying Behavior

impulsiveness (Eysenck et al. 1985; Rook and Fisher 1995). These items were tested on a convenience sample of 160 graduatemanagement students. Exploratory factor analysis, correlation tests, and confirmatory factor analysis were used to purify the measures across the pretest and study samples. A confirmatory factor analysis on our final ten-item measure of buying impulsiveness suggest an acceptable model, with chi-square statistic of 47.42 $(\mathrm{df}=29 ; \mathrm{p}<.01)$ : an adjusted goodness of fit index (AGFI) of .89: a comparative fit index (C171) of .94; and a norm fit index (NE) of .9 1. All lambda coefficients are large and significant, and all $t$-values exceed $9.0(\mathrm{p}<.001)$. The scale's mean = 23,1, SD 7.6, and Cronbach's alpha $=.89$. The ten items that make up our buying impulsiveness scale are identified in Table 2 , along with their factor loading, means, and standard deviations.

\section{Measurement of Impulsive Purchase Decision}

Our dependent variable relies on a single-item measure that forces respondents to choose what the consumer describes in the following imaginary shopping situation would do "Dilla is a 23 yearold undergraduate student with a part-time job. It is two days before Dilla gets her next paycheck and she has only 25.000 rupiah left for necessity. In addition to food, Dilla needs to buy a pair of shoes for graduation day this weekend. After finishing her work, she goes with her boy friend, Denny, to the mall to purchase the shoes. As they are walking through Matahari department store, Dilla sees a great looking women's handbag on sale for 100,000 rupiah."

After reading this scenario, respondents were instructed to select which one of five purchase decision alternatives Dilla would make. These choice alternatives were designed to represent varying levels of buying impulsiveness. From low to high impulsiveness, these alternatives were: (1) buying the shoes only, (2) wishing the handbag but not buying it, (3) deciding not to buy shoes, (4) buying both the shoes and women's handbag with a credit card, and (5) buying these plus matching slacks and a shirt, also with a credit card.

The use of this imaginary stimulus situation assumes that respondents will project themselves into the shopping scenario presented and that the impulsive buyers among the respondents will be more likely to select an impulsive purchase choice. Also, an indirect questioning approach should reduce the likelihood that social desirability biases will encourage "correct" but dishonest responses (Fisher 1993). To control for possible gender effect of the stimulus, half of the sample was exposed to an identical scenario that included a male imaginary character. An ANOVA was run on character gender as an independent variable. Because no significant gender effects were found, data from the two conditions were pooled.

\section{Normative Evaluation}

Hypothetically, this buying situation invites either negative or positive normative evaluations. Dilla is low on cash and should be practical and frugal, but the upcoming graduation day may encourage and impulsive spend extravagantly. Although impulse buying transpires quickly and without extensive consideration, this does not preclude the possibility that consumers make on the-spot evaluations of a prospective purchase. Our normative evaluation measure assumes that consumers may assess the appropriateness of buying something on impulse along a continuum that range from relative neutrality 
to either strong disapproval or encouragement.

After the respondents indicated which purchase decision they believed that Dilla would make, they were instructed to imagine that she actually bought both the unplanned $\mathrm{Rp} 100,000$ women handbag and the planned shoes. Respondents' normative evaluations of this relatively impulsive purchase decision were gathered from a semantic differential scale that operationalized the normative dimensions we discussed earlier. The ensuing scale included these 10 bipolar adjective pairs (Rook and Fisher 1995): good-bad, rational-crazy, wasteful-productive, attractiveunattractive, smart-stupid, acceptable-unacceptable, generous-selfish, sober-silly, mature-childish, and right-wrong. The mean of normative evaluation scale $=31,5$, $\mathrm{SD}=6.7$, and Cronbach's $(\alpha=.94)$.

\section{Results}

Rook and Fisher hypothesize that consumers' normative evaluation moderates the degree or strength of relationship between the buying impulsiveness trait and impulse buying behavior. The appropriate test of difference in the trait-behavior relationship across different normative conditions is an of product-moment correlation across normative subgroups (Arnold 1982). Another reason for using group analysis is our hypothesis that the effect of consumer's impulse buying norms as a trait-behavior moderator is not likely a continuos one. By nature, normative evaluations tend to be dichotomous, and their behavior influence often communicates either a summary yes or no to some anticipated action. In the context of impulse buying, this idea suggest that normative influence operates as a behavior "gate" that is either open or closed, with little or no middle ground. Thus, the relationship between consumers' impulse buying tendencies and their impulse buying behavior should be strong when normative evaluations are approving but weaker when some negative normative threshold is reached, which mutes consumers' trait tendencies. Given this hypothesis, it is appropriate to split the sample into subgroups (Hair et al. 1995).

Following Rook and Hoch, we used median split on respondents' normative evaluations of the impulsive women handbag purchase to divide the sample into favorable $(\mathrm{n}=80)$ and unfavorable $(\mathrm{n}=$ 80) subgroups. Respondents' own buying impulsiveness and the impulsiveness of their hypothetical purchase decision were significantly related in the favorable norm group $(\mathrm{r}=.46, \mathrm{t}=4.42, \mathrm{p}<.01)$. In other words, impulsive respondent who evaluated Dilla's unplanned handbag purchase positively were also likely to have projected an impulsive purchase decision for her. In the unfavorable norm group, however, the trait behavior relationship was not significant $(\mathrm{r}=-.005, \mathrm{t}=-.04, \mathrm{p}>.10)$. When the handbag purchase was evaluated negatively, the respondents' buying impulsiveness had no effect on the purchase decisions they made for Dilla. A fisher's $z$-transformation revealed that the two correlations differed significantly $(\mathrm{z}=$ $2.45, \mathrm{p}<.01$, one-tailed). These results reinforce the conclusion by Rook and Hoch that consumers' normative evaluation moderates the link between the trait and behavioral aspect of impulse buying.

To examine the robustness of the finding with different basis for defining normative subgroups, the sample was divided into three groups and the withingroup correlation was computed. A simi- 
Negara \& Dharmmesta - Normative Moderators of Impulse Buying Behavior

lar pattern of results occurred. The correlation between buying impulsiveness and projective measure of impulse buying was significant only within the most favorable group $[\mathrm{r}($ favorable $)=.46, \mathrm{t}=3.87, \mathrm{p}<.01$, $\mathrm{n}=64 ; \mathrm{r}$ (neutral) $=.15, \mathrm{t}=.88, \mathrm{p}>.10, \mathrm{n}$ $=64 ; \mathrm{r}($ unfavorable $)=.18, \mathrm{t}=.74, \mathrm{p}>.10$, $\mathrm{n}=82]$. This supports the idea that the effect of consumers' impulse buying norms as a trait behavior moderator is not linear. Consumers' impulse buying tendencies may be most likely to express themselves in actual impulsive purchase only when some normative threshold is reached.

\section{Discussion}

This study shows that the emergent impulse buying behavior occurs when a consumer experiences a sudden, often powerful and persistent urge to buy something immediately. When a consumer feels that impulse buying is acceptable in a particular context, a positive relationship should exist between the buying impulsiveness and following behavior. Because normative constraints are keeping away, the consumer is free to act on his or her impulsive buying tendencies. On the contrary, in situations where consumers believe it is unacceptable to buy something on impulse, they will be constrained by norms that dishearten or forbid the contemplated behavior.

The known facts in the favorable norm group advocate the opinion that consumers with positive normative evaluations are more probable to act in a way that is consistent with the degree to which they posses the buying impulsiveness characteristic. The lack of a significant association between the trait and behavior in the unfavorable norm group is also as hypothesized, but the reasons for this finding appear more complex. Individuals who have low impulsive tendencies and who also judge a possible impulse purchase negatively are unlike to act on their buying impulses in such situations. However, when more impulsive consumers view a purchase as bad, they are likely to feel varying degrees of ambivalence. These individuals feel almost simultaneously an arousing and spontaneous impetus to buy and a strong normative warning against acting on impulse. In some situations, individuals may feel deserving and frustrated; yet resist the urge to buy. In other instances, the buying impulse may "succeed" when consumers ignore or rationalize exceptions to normative considerations. The very sense of violating prevalent norms may generate additional hedonic arousal and increase the likelihood of a purchase. Because of the possible variation in consumers' normative responses, the buying impulsiveness trait was lees likely to predict (projective) behaviors when normative evaluations were unfavorable.

The results of this study imply that consumers' normative evaluations can moderate the link between the trait and behavioral aspect of impulse buying. The overall correlation between respondents buying impulsiveness and their projected purchase decision for Denny or Dilla was significant, but not particularly strong $(\mathrm{r}=$ $.25, \mathrm{t}=2.47, \mathrm{p}<.01)$. However, this relationship is clarified by including normative component as trait-behavior moderators. Indeed, the association between buying impulsiveness and impulsive buying is considerably weaker when the anticipated behavior is perceived to be inappropriate, and considerably stronger when a prospective purchase is evaluated positively. These findings provide some support for the moderating role of normative evaluations in the relationship between buying impulsiveness and impulse buying. 


\section{Limitations and Future Research}

This study has limitation that suggests important direction for future research. First, future researcher needs to examine the relationship between buying impulsiveness and impulse buying with sample of non-student respondents. This is important in order to get more representative retail customers in an actual shopping or retail environment and how they perform their behavior. Usually, customers remember immediately specific brands or products when they are in a shopping environment. This can impact on impulse buying.

Second, further research is needed on the differences between impulse buying and unplanned purchase. Unplanned purchase included items for which the purchasing decision was made in the store and not prior to entering the store. Indeed, all impulse buying is unplanned, but all unplanned purchase is not necessarily bought on impulse. Also, unplanned purchasing is the opposite of shortfall, which is defined as the number of items a shopper planned to buy but did not (Iyer 1989).

Finally, the result of this study cannot be generalized beyond the present sample. Because the characteristics of sample in this study are not representative excluding customers with certain purchasing pattern such as a housewife or disperse locations. However, this study has provided a reasonable test for existence of impulse buying behavior. For marketing researchers, al least, the current study provides understanding of the evidence purchasing behavior pattern. Thus, the study of impulse buying may provide valuable ideas for the study of consumer behavior is general as well as being an important topic in its own right.

\section{References}

Ainslie, G. 1975. Specious reward: A behavioral theory of impulsiveness and impulse control. Psychological Bulletin (July): 463-496.

Ajzen, I., and M. Fishbein. 1977. Attitude-behavior relations: A theoretical analysis and review of empirical research. Psychological Bulletin 84 (September): 888-918.

Arnold, H. J. 1982. Moderator variables: A classification of conceptual, analytic, and psychometric issues. Organizational Behavior and Human Performance 29 (April): 143-174.

Assael, H. 1995. Consumer Behavior and Marketing Action (6 ${ }^{\text {th }}$ Ed.). Ohio: SouthWestern College Publishing.

Bawa, K., J.T. Lanwehr, and A. Krishn. 1989. Consumer response to retailers: Marketing environments. Journal of Retailing (Winter): 471-95.

Bellenger, D. X., D. H. Robertson, and E. C. Hirschman. 1978. Impulse buying variety by product. Journal of Advertising Research 18:15-18.

Bettman, J. R. 1979. An Information Processing Theory of Consumer Choice. Reading, M.A: Addison-Wesley. 
Negara \& Dharmmesta - Normative Moderators of Impulse Buying Behavior

Birenbaum, A., and E. Sagarin. 1976. Norm and Human Behavior. New York: Praeger.

Clover, V. T. 1950. Relative importance of impulse buying in retail stores. In Loudon, D. L. and Bitta, A.J. D.: Consumer Behavior. Concept and Applications ( $4^{\text {th }} \mathrm{Ed}$.). New York: McGraw-Hill, Inc.: 66-70.

Cobb, C. J., and W. D. Hoyer. 1986. Planned versus impulse purchase behavior. Journal of Retailing (Winter): 384-409.

Cox, K. R. The responsiveness of food sales to shelf-space change in supermarket. Journal of Marketing Research 1 (May): 63-68.

Eyserick, S. B., and B. J. McGurk. 1980. Impulsiveness and venturesomeness in a detention center population. Psychological Reports 47 (December): 1989-1993.

Fisher, R. J. 1993. Social desirability bias and the validity of indirect questioning. Journal of Consumer Research 20 (September): 302-315.

Granbois, D. H. 1968. Improving the study of customer in-store behavior. Journal of Marketing 32: 28-33.

Hair, J. F., R. E Anderson, R. L. Tatham, and W. C. Black. 1995. Multivariate Data Analysis with Reading ( $4^{\text {th }}$ Ed.). New Jersey: Prentice-Hall, Inc.

Harris D. H. 1958. The effect of display width in merchandising soap. Journal of Applied Psychology: 283-289.

Hawkins, D. L, R. J. Best, J. Roger, and K. A. Coney. 1998. Consumer Behavior Building Marketing Strategy ( $7^{\text {th }}$ Ed.). Irwin: McGraw Hill.

Hilgrad, E. R. 1962. Impulse versus realistic thinking: An examination of the distinction between primary and secondary processes in thought. Psychological Bulletin 59 (November): 477-488.

Hirschman, E. C. 1992. The consciousness of addiction: Toward a general theory of compulsive consumption. Journal of Consumer Research 19 (September): 155-179.

Hoch, S. J. and G. F. Loewenstein. 1991. Time-inconsistent preferences and consumer self control. Journal of Consumer Research 17 (March): 492-507.

Iyer, E. S. 1989. Unplanned purchasing: Knowledge of shopping environment and time pressure. Journal of Retailing 65 (Spring): 40-57.

Kollat, D. T., and R. P. Willett. 1967. Customer impulse purchasing behavior. Journal of Marketing Research 4 (February): 21-31.

Kollat, D. T., and R. P. Willett. 1969. Is impulse purchasing really a useful concept in marketing decisions. Journal of Marketing 33 (January): 79-83.

Kotzman, J. F., and R. Evanson. 1969. Responsiveness of drug store sales to shelf-space allocation. Journal of Marketing Research 6: 465-470.

Loudon, D. L., and A. J. D. Bitta. 1993. Consumer Behavior. Concept and Applications ( $4^{\text {th }}$ Ed.). New York: McGraw-Hill, Inc. 
McKenna, M. L. 1966. The influence of in-store advertising. In Easwar S. Iyer (Unplanned Purchasing: Knowledge of Shopping Environment and Time Pressure): Journal of Retailing.

McClure, P. J., and E. J. West. 1969. Sales effect of new counter display. In Park C. W., E. S. Iyer, and D. S. Smith (The Effect of Situational Factors In-Store Grocery Shopping Behavior): Journal of Consumer Research 15: 422-433.

Park, C. W., E.S. Iyer, and D. S. Smith. 1989. The effect of situational factors on in store grocery shopping behavior. Journal of Consumer Research (March): 422-33.

Prasad, V. K. 1975. Unplanned buying in two retail settings. In D. L. Loudon, and A. J. Della-Bitra (1993): Consumer Behavior: Concept and Applications ( $4^{\text {th }}$ Ed.). New York: McGraw-Hill, Inc.

POPAI. 1995. Consuming buying habit study. In L Hawkins, R. J. Best and K. A. Coney: Consumer Behavior: Building Marketing Strategy $\left(7^{\text {th }}\right.$ Ed.). Irwin: McGraw-Hill.

Robertson, H. and E.C. Hirschman. 1978. Impulse buying varies by product. In D. L. Loudon, and A. J. Della-Bitra (1993): Consumer Behavior: Concept and Application. New York: McGraw-Hill, Inc.

Rook, D. W. 1987. The buying impulse. Journal of Consumer Research 14 (September): 189199.

Rook, D. W., and R. J. Fisher. 1995. Normative influences on impulsive buying behavior. Journal of Consumer Research 22 (December): 305-313.

Rook, D. W., and S. J. Hoch. 1985. Consuming impulses. In Morris B. Holbrook and E. C. Hirschman.: Advances in Consumer Research 12: 23-27. Provo, UT.

Russo, J. E., and F. Lecleric. 1994. An eye fixation analysis of choice processes for consumer nondurables. Journal of Consumer Research (September): 274-90.

Stigler, G. J., and S. B. Gary. 1977. De gustibus non est disputandurn. In Dennis W. R. and Robert J. F.: Normative Influences on Impulsive Buying Behavior: 76-90 .

Thaler, R. H., and H. M. Shefrin. 1981. An economic theory of self-control. Journal of Political Economy 89: 392-406.

Weinberg, P. and W. Gottwald. 1982. Impulsive consumer buying as a result of emotions. Journal of Business Research 10: 43-57.

Wolman, B. B. 1977. Dictionary of Behavioral Science. New York: Van Nostrand Reinhold Co. 